\title{
Maternal care in captive grey hamster Cricetulus migratorius (Rodentia, Cricetidae)
}

\author{
Vladimir S. Gromov, Alexey V. Surov \& Georgy B. Ryurikov
}

\begin{abstract}
In ten female grey hamsters, Cricetulus migratorius, rearing their first litters, both direct and indirect maternal activities were studied under laboratory conditions during the observation period (21 days from parturition) divided into four rearing stages: days $2-6,7-11,12-16$, and $17-21$, respectively. The maternal care was found to include nursing, huddling over, brooding and grooming the young, the nest construction and food caching. Total time spent in the nest by the females was found to decrease gradually during the whole observation period as well as other maternal activities with exception of pup grooming that has maximum rate during second rearing stage. Maternal behaviour of Cricetulus migratorius is discussed in comparison with that one of other cricetid rodents.
\end{abstract}

KEY WORDS: hamster, maternal care, nest attendance, pup grooming, nest maintenance.

Vladimir S. Gromov [gromov@sevin.chg.ru], Alexey V. Surov, and Georgy B. Ryurikov, A.N. Severtsov Institute of Ecology and Evolution, Russian Academy of Sciences, Leninskii pr. 33, Moscow 119071, Russia.

\section{Забота о потомстве у серого хомячка Cricetulus migratorius (Rodentia, Cricetidae) в лабораторных условиях}

\author{
В.С. Громов, А.В. Суров, Г.Б. Рюриков
}

\begin{abstract}
РЕЗЮМЕ. В лабораторных условиях изучали особенности родительского поведения у 10 самок серого хомячка (Cricetulus migratorius), выкармливающих первые выводки. Наблюдения проводили со второго по 21 день после рождения детенышей. Для оценки изменений материнского поведения по мере роста детенышей весь период наблюдений разделили на четыре пятидневки: 2-6, 7-11, 12-16 и 17-21-й дни. Установлено, что у самок серого хомячка хорошо выражена как прямая, так и косвенная забота о потомстве: кормление детенышей молоком, их обогревание и чистка (вылизывание), гнездостроение и доставка корма в гнездо. Все показатели, характеризующие интенсивность заботы о детенышах, снижались по мере их роста, за исключением чисток, продолжительность которых была максимальной не в первую, а во вторую пятидневку. В последнюю пятидневку все проявления материнской заботы сократились до минимума. Проведено сравнение показателей родительского поведения серого хомячка с другими представителями семейства Cricetidae.
\end{abstract}

КЛЮЧЕВЫЕ СЛОВА: серый хомячок, родительское поведение, чистка детенышей, гнездостроение.

\section{Introduction}

Sex and species differences in the parental behaviour of rodents as well as proximate and ultimate mechanisms underlying them are of the great interest for many ecologists and ethologists during the last threefour decades. It is well known that exclusive maternal care is expected in about $90 \%$ rodent species (Kleiman, 1977). Maternal behaviour was found to be variable among different rodent species, but this variability is poorly investigated. Among rodents, only three hamster species (Mesocricetus auratus, Phodopus sungorus and $P$. campbelli) have been involved in these investigations (Rowell, 1960, 1961; Noirot \& Richards, 1966; Richards, 1966; Daly, 1972; Buntin et al., 1984; WynneEdwards, 1987, 1995, 1998). This article focuses on the maternal care of another species, namely the grey hamster, Cricetulus migratorius.
Very little data are available on the behaviour of the grey hamster in nature. The area of this species includes steppes and other arid regions of European part of Russia, Ukraine, Turkey, Iran, Afghanistan, Kazakhstan, and northwestern China (Bashenina, 1951). Observations in nature showed that both males and females occupy individual home ranges that little overlap ranges of same-sex conspecifics (Vasilieva \& Surov, 1984). Regular periods of above-ground activity of lactating female grey hamsters were found to average 109.1 \pm 21.8 minute, and were significantly shorter than that ones of males (in average $151.3 \pm 18.6$ minute). Adult individuals seemed to avoid both direct contacts with conspecifics and entering their burrows. Pair bonds are very weak, and male-female interactions occur mainly during the mating bouts. Paired encounters of adult individuals on a neutral arena revealed a high aggression of the hamsters toward conspecifics irrespective of their sex. 
In this study, amount of maternal care in Cricetulus migratorius was measured in order to further our knowledge about parental care among cricetid rodents.

\section{Materials and methods}

Animals and housing conditions. Animals used in this study were laboratory-bred descendants (secondor third-generation offspring) of the grey hamsters originally trapped in nature in different regions of the European part of Russia in 2000-2003. Observations were carried out on 10 females rearing their first litter. All the animals used in the study were in good physical condition. Each female was housed alone in a $30 \times 35 \times 20$ $\mathrm{cm}$ plastic cage with wood shavings as bedding. All animals were maintained on natural photoperiod varying from $12 \mathrm{~L}: 12 \mathrm{D}$ to $16 \mathrm{~L}: 8 \mathrm{D}$, i.e. with a long light phase. Animals were fed on mixture of oats and sunflower seeds and fresh vegetables (carrot, cabbage, beetroots, and apples). Years of experience in maintaining lab colonies of the grey hamster at the Institute field station have shown that provision of water is unnecessary if sufficient fresh vegetables are provided.

When pregnant females were nearing parturition (4-7 days before birth of the litter), each of them was transferred to a $60 \times 30 \times 35 \mathrm{~cm}$ glass aquarium with a thin layer of sawdust on the bottom. Every aquarium was equipped with a wooden nest chamber $(17 \times 15 \times 8$ $\mathrm{cm})$ with wood shavings as bedding inside. Each nest chamber had transparent plastic top to allow direct observation of the females and their offspring. The aquariums were placed in a quiet room with natural (uncontrolled) illumination (from 12L:12D to $16 \mathrm{~L}: 8 \mathrm{D}$ ) during the whole observation period. Animals were fed ad lib as described above.

Behavioral observations. All observations were started within the period from 19:00 to $24: 00$, the time of peak activity in this species under laboratory conditions, and the beginning of every next observation was shifted by 1-2 $\mathrm{h}$ to eliminate the effect of starting time. During total observation period, the test aquarium was additionally illuminated with $25 \mathrm{~W}$ electric lamp attached in $1 \mathrm{~m}$ above. Every female was observed on the day 2 postpartum and thereafter till day 21 every $1-2$ days, each for $1 \mathrm{~h}$ or a bit more. Duration of the observation period (up to 21 day) was chosen to make comparison of the maternal behaviour of the grey hamster with that one of other cricetid rodents, including voles, although the weaning of young in C. migratorius may begin at 17-18 days. Exact time at which the female left or entered nest chamber was recorded. This information was used to calculate total time spent with young for every female under study. Besides, following female activities were recorded: duration of pup grooming (licking), frequency of manipulations with bedding in the nest chamber, frequency of bringing nest material (wood shavings) into the nest chamber, frequency of bringing of food into the nest (food cashing).

Data analysis. Data collected were grouped into four rearing periods (stages) in dependence on age of pups: days $2-6$, days $7-11$, days $12-16$ and days $17-$ 21 , with three $1 \mathrm{~h}$ observation sessions per each stage for each female. As not all of the variables were normally distributed, the Wilcoxon matched pairs test was used to assess the significance of differences between the stages. An average value of each parameter was calculated from the three observation sessions to provide a mean value $(\mathrm{M} \pm \mathrm{SE})$ of the parameter for each rearing period for each female and its activities. Coefficients of Spearmen rank order correlation (R) were calculated between numbers of pups in litters and mean values of each behavioural parameter. In all statistical comparisons, alpha level was set to 0.05 .

\section{Results}

Repertoire of maternal behaviours. Females displayed all the patterns of direct care of young including nursing, huddling over and grooming (licking) the pups. The females displayed a kyphosis posture (the arched suckling position) when brood pups. Such a posture was described earlier for Rattus norvegicus (Stern \& Johnson, 1990), Microtus ochrogaster (Lonstein \& De Vries, 1999) and Lasiopodomys mandarinus (Smorkatcheva, 2003). Besides, females showed indirect parental care including manipulations with bedding, collection and hoarding nest material. They also were engaged in food cashing.

Correlation of maternal behaviours and litter size. Quantity of pups in the litters varied from 2 to 7. All the maternal activities were found to be independent on litter size: Spearmen rank order correlation $0.21<\mathrm{R}<0.58,0.077<p<0.957$.

Relative amount of maternal care. Nursing time has been not estimated because the pups were hardly visible nearly all the observation time during the first and second rearing periods being under the belly of the females.

Nest attendance. Females spent more time in the nest during first rearing period (in average, 46.1 \pm 3.5 minute per 1 hour, lim: 17.1-55.0) compared with second and the next other ones (Fig. 1, I) but there was no

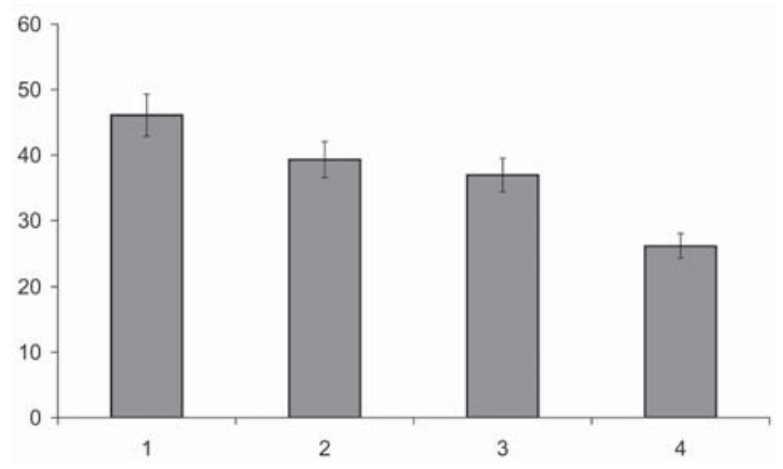

Figure 1. Total time ( $\mathrm{M} \pm \mathrm{SE}$, min per one hour) spent by female in the nest with pups of different ages. Horizontal axis shows rearing periods $(1-4)$. 


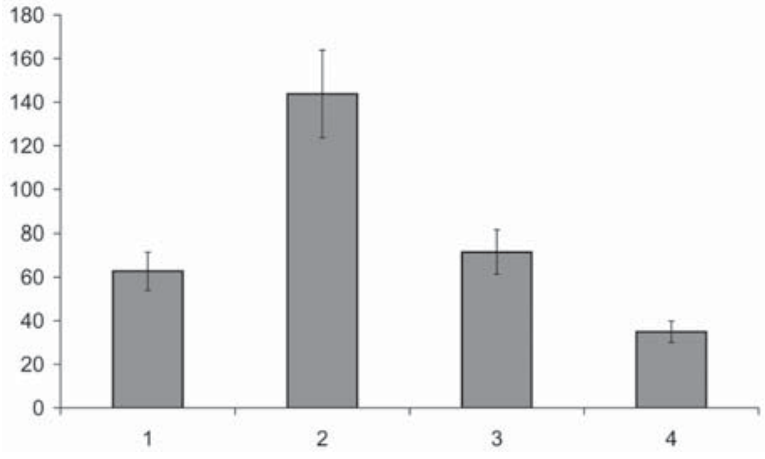

Figure 2. Duration ( $\mathrm{M} \pm \mathrm{SE}$, s per one hour) of pup grooming. Horizontal axis shows rearing periods (1-4).

essential decrease in average values of this parameter excluding the difference between fourth stage (in average, 26.2 \pm 2.8 minute per 1 hour, lim: $0-58.2$ ) and three previous ones (Wilcoxon match paired test, $p<0.022$ ).

Pup grooming. Duration of pup grooming during second rearing stage (in average, $144 \pm 32 \mathrm{~s}$ per 1 hour, lim: 50-375) was significantly greater (Fig. 2, 2) then that one during first rearing stage (in average, $63 \pm 14 \mathrm{~s}$ per 1 hour, lim: 14-169) and two other rearing periods (Wilcoxon match paired test, $p<0.022$ ). Females spent minimum time grooming the pups by the end of the whole observation period (in average, $35 \pm 6 \mathrm{~s}$ per 1 hour, lim: 4-88).

Nestbuilding. Activity of females in nestbuilding (bringing wood shavings for bedding into the nest chamber) was highest during 1-2 days before parturition. After parturition, such an activity was found to be low and irregular. (Fig. 3, II). During first rearing period, average estimation of this activity was $1.2 \pm 0.5$ score per one hour, and during fourth stage no females were observed to bring wood shavings into the nest.

Nest maintenance. Manipulations with bedding inside the nest chamber were observed relatively frequently (Fig. 3, I). Such an activity was found to be highest during first and second rearing periods and averages $16.7 \pm 2.4$ score per one hour (lim: 6-29). By the end of the whole observation period, frequency of manipulations with bedding was significantly decreased, and during fourth rearing stage it averaged 5.5 \pm 1.7 score per 1 hour (lim: 0-14). Difference in rate of nest maintenance during two first rearing stages and fourth one was significant (Wilcoxon match paired test, $p=0.017)$.

Food cashing. Females brought vegetables, oats and sunflower seeds into the nest chamber at the end of every period of outside activity. Quantity of these periods varied from 1 to 5 per one hour during all the rearing stages. At the age of 10-12 days, pups began to eat pieces of the vegetables brought into the nest by the female.

\section{Discussion}

General pattern of aggression of the female grey hamsters toward male conspecifics both under labora-

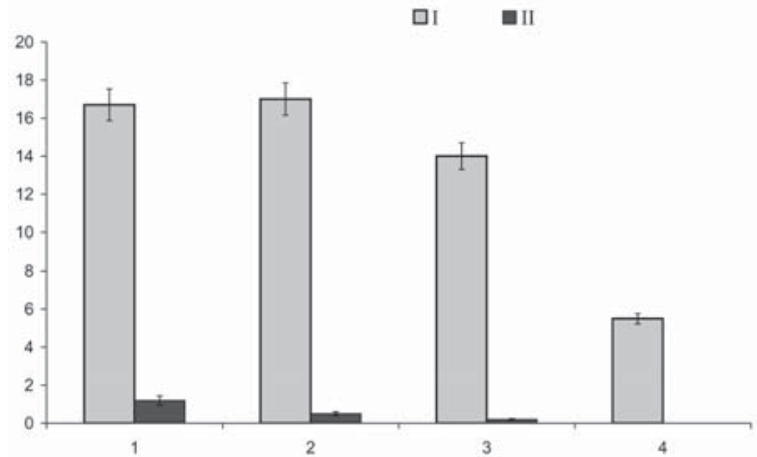

Figure 3. Frequency ( $\mathrm{M} \pm \mathrm{SE}$ per one hour) of manipulations with bedding (I) and bringing wood shavings into the nest (II). Horizontal axis shows rearing periods (1-4).

tory and natural conditions (Vasilieva \& Surov, 1984) seems to prevent essential paternal investment in this species, and results in uniparental (maternal) care like in the golden hamster, M. auratus (Rowell, 1960, 1961; Noirot \& Richards, 1966; Richards, 1966; Daly, 1972; Buntin et al., 1984). The present study quantified the maternal activities of $C$. migratorius and revealed that the females under study spent much time out of their nest and displayed relatively little maternal behaviour, especially during the last rearing stage (time of weaning). It is surprisingly that no maternal activities were found to correlate with the number of pups in the litters. Thus, every pup in larger litters received less amount of the total maternal care as compared with pups in smaller litters.

A high degree of concordance appears to exist between the results of the present study and the reports of the grey hamster social organization (Bashenina, 1951; Vasilieva \& Surov, 1984) indicating that females of this species are territorial, self-sufficient rearing units. In terms of maternal care, the female grey hamsters exhibited behavioural trends similar to those reported for females of some other cricetid rodents, particularly the golden hamster, M. auratus, and Siberian hamster, $P$. sungorus (Daly, 1972; Wynne-Edwards, 1995, 1998).

Unfortunately, it is difficult to carry out correct interspecies comparison among cricetid rodents because authors of other studies used different experimental conditions, testing procedures and behaviour sampling. For example, to quantify the maternal care in the golden hamster, some authors recorded and analysed the retrieval behaviour only in virgin or pregnant females during the tests carried out in individual cages where the females were offered pups between three and eleven days old (Rowell, 1960, 1961; Noirot \& Richards, 1966; Richards, 1966; Buntin et al., 1984). For $P$. campbelli and P. sungorus (Wynne-Edwards, 1995), the author observed litters reared by solitary mothers and by mother-father pairs with recording such a parental activity as nest attendance as scan samples (Altmann, 1974) on the minute, every minute for a total of $60 \mathrm{~min}$ daily. For $M$. auratus, $P$. campbelli and $P$. sungorus, no authors appropriately recorded such a 
parameter as duration of pup grooming. Thus, interspecies comparison of the nest attendance and pup grooming could not be correctly made for the cricetid rodents under consideration.

However, it is possible to make such a comparison for the grey hamster and some vole species, for example Microtus pennsylvanicus, M. ochrogaster, Lasiopodomys mandarinus and L. brandtii, which parental activities have been studies appropriately in terms of methods and parameters used (McGuire \& Novak, 1984; Smorkatcheva, 2003; Gromov, 2005). The female meadow voles, M. pennsylvanicus, are considered territorial, self-sufficient rearing units (McGuire \& Novak, 1984) like females of many hamster species. The meadow vole is probably promiscuous (Getz, 1972) whereas the prairie vole, $M$. ochrogaster, mandarin vole, $L$. mandarinus, and Brandt vole, L. brandtii, live in relatively stable family units (Getz \& Carter, 1980; Smorkatcheva, 1999; Gromov, 2003).

Observations in captivity revealed substantial differences in parental behaviour of the meadow vole as compared with the prairie vole (McGuire \& Novak, 1984), mandarin vole (Smorkatcheva, 2003), and Brandt vole (Gromov, 2005). In general, female meadow voles spent more time out of their nest and displayed less maternal behaviour than the female prairie, mandarin, and Brandt voles. For example, female meadow voles were out of nest in average $75.0 \%$ of the observation time (McGuire \& Novak, 1984). The same parameter measured for female prairie, mandarin, and Brandt voles averaged 34.7, 18.7, and 11.4\%, respectively (McGuire \& Novak, 1984; Smorkatcheva, 2003; Gromov, 2005). Pup grooming by the female meadow voles averaged $106 \mathrm{~s}$ per 1 hour, and the same activity in female prairie, mandarin, and Brandt voles was estimated in average 100, 169 and 79 s per one hour, respectively. Furthermore, although paternal care was well developed in the prairie, mandarin, and Brandt voles, none was ever observed in the meadow vole. Finally, meadow vole pups showed more rapid behavioural development than pups of the remaining vole species.

The results of our study show that the female grey hamsters were out of nest in average $38.3 \%$ of the observation time, and groomed pups in average $78 \mathrm{~s}$ per one hour. When viewed as a whole, there is obvious similarity in amount of the maternal care and some other behavioural traits of the meadow vole and grey hamster. Females of both species seem to be territorial, self-sufficient rearing units, and usually aggressive towards males and also intolerant to older offspring. As lactation progressed, females of both species showed increased movement and decreased time spent in the nest. Weaning occurred substantially earlier both in the meadow vole and grey hamster as compared with three above vole species, suggesting that the pups of the meadow vole and grey hamster, like in other hamster species, are more precocious than pups of other vole species with relatively stable family units.

In summary, our findings not only provide support for the proposed promiscuous mating system of the grey hamster like in other cricetid rodents with similar social organization, but also suggest that both mating system and parental investment influence variation in the life-history strategies of different rodent species. Thus, further investigations are needed to understand common generalities concerning interrelation between parental care and social organization of rodents.

ACKNOWLEDGEMENTS. This study was supported by the Scientific Programme of Russian Academy of Sciences "Biodiversity and dynamics of genofond" (subprogram "Biodiversity", grant 6.1.5).

\section{References}

Altmann J. 1974. Observational study of behavior: sampling method // Behaviour. Vol.49. No.3. P.227-267.

Bashenina N.V. 1951. [Ecology of the grey hamster (Cricetulus migratorius Pall.) inhabiting the European part of the USSR] // Fauna and Ecology of Rodents. Vyp.4. P.157-183 [in Russian].

Buntin J.D., Jaffe S. \& Lisk R.D. 1984. Changes in responsiveness to newborn pups in pregnant, nulliparous golden hamsters // Physiology and Behavior. Vol.32. No.3. P.437-439.

Daly M. 1972. The maternal behaviour cycle in golden hamsters (Mesocricetus auratus) // Zeitschrift für Tierpsychologie. Bd.31. Hf.3. P. 289-299.

Getz L.L. 1972. Social structure and aggressive behavior in a population of M. pennsylvanicus // Journal of Mammalogy. Vol.53. No.2. P.310-317.

Getz L.L. \& Carter C.S. 1980. Social organization in Microtus ochrogaster populations // The Biologist. Vol.62. P.56-69.

Gromov V.S. 2003. [Territorial structure and social organization in Brandt vole (Lasiopodomys brandti) under semi-natural conditions] // Zoologicheskii Zhurnal. Vol.82. No.7. P.852-861 [in Russian with English summary].

Gromov V.S. 2005. Parental care in captive Brandt vole (Lasiopodomys brandti) // Russian Journal of Theriology. Vol.4. No.2. P.137-145.

Kleiman D.G. 1977. Monogamy in mammals // Quarterly Review of Biology. Vol.52. P.39-69.

Lonstein J.S. \& De Vries G.J. 1999. Comparison of the parental behaviour of pair-bonded female and male prairie voles (Microtus ochrogaster) // Physiology and Behavior. Vol.66. No.1. P.33-40.

Noirot E. \& Richards M.P.M. 1966. Maternal behaviour in virgin female golden hamsters: changes consequent upon initial contact with pups // Animal Behaviour. Vol.14. No.1. P.7-10.

McGuire B. \& Novak M. 1984. A comparison of maternal behaviour in the meadow vole (Mictotus pennsylvanicus), prairie vole (M. ochrogaster) and pine vole ( $M$. pinetorum) // Animal Behaviour. Vol.32. P.1132-1141.

Richards M.P.M. 1966. Maternal behaviour in virgin golden hamsters (Mesocricetus auratus Waterhouse): the role of the age of the test pup // Animal Behaviour. Vol.14. No.3. P.303-309. 
Rowell T.E. 1960. On the retrieving of young and other behaviour in lactating Golden hamsters // Proceedings of the Zoological Society of London. Vol.135. P.265-282.

Rowell T.E. 1961. Maternal behaviour in non-maternal golden hamsters // Animal Behaviour. Vol.9. No.1. P.11-15.

Smorkatcheva A.V. 1999. The social organization of the mandarin vole, Lasiopodomys mandarinus, during the reproductive period // Zeitschrift für Säugetierkunde. Bd.64. Hf.6. P.344-355.

Smorkatcheva A.V. 2003. Parental care in the captive mandarin vole, Lasiopodomys mandarinus // Canadian Journal of Zoology. Vol.81. No.8. P.1339-1345.

Stern J.M. \& Johnson S.K. 1990. Ventral somatosensory determinants of nursing behavior in Norway rats: I. Effects of variations in the quality and quantity of pup stimuli. Physiology and Behavior. Vol.47. No.5. P.9931011.
Vasilieva N.Yu. \& Surov A.V. 1984. [Spatial population structure and behaviour of the grey hamster in the Transaltai Gobi Desert, Mongolian People Republic] // Sokolov V.E. (ed.). [Communication and Ecology of Mammals and Birds]. Moskva: Nauka. P.113--120 [in Russian].

Wynne-Edwards K.E. 1987. Evidence for obligate monogamy in the Djungarian hamster, Phodopus campbelli: Pup survival under different parenting conditions // Behavioural Ecology and Sociobiology. Vol.20. No.6. P.427-437.

Wynne-Edwards K.E. 1995. Biparental care in Djungarian but not Siberian dwarf hamsters (Phodopus) // Animal Behaviour. Vol.50. P.1571-1585.

Wynne-Edwards K.E. 1998. Evolution of parental care in Phodopus: conflict between adaptations for survival and adaptations for rapid reproduction // American Zoologist. Vol.38. No.1. P.238-250. 